\title{
BUYING OUT INSURGENT SHAREHOLDERS WITH CORPORATE FUNDS*
}

MANagement's use of corporate funds to purchase stock held by potential insurgents may protect the corporation from being taken over by less competent or perhaps unscrupulous management, but the power to make such purchases is also an effective device which the incumbent management may use to insulate its position against shareholder action. Management already possesses significant advantages when its control is challenged in a proxy contest; these include the power to use corporate funds for reasonable solicitation expenditures, ${ }^{1}$ control over the proxy machinery, ${ }^{2}$ the favor of financial institutions holding large blocks of voting stock, ${ }^{3}$ and the benefit of inertia supporting the status quo. ${ }^{4}$ Proxy contests for control are still waged, however, and sometimes won. ${ }^{5}$ Therefore, the incumbent management may seek other means to prevent the proxy contest from materializing. Those in control can accomplish this end if, acting as shareholders, they use private funds to buy out the insurgents or to purchase an absolute or working majority of the voting shares.

If the directors cause the corporation to purchase its own shares for this purpose, however, their action may be found a violation of the directors' obligations to the corporation and its stockholders. Of those jurisdictions in which the law grants a corporation the general power to purchase its shares, ${ }^{\circ}$ only Massachusetts, Wisconsin, and Delaware appear to have dealt specifically with this problem. ${ }^{\top}$ A Massachusetts court has held that when a corporation

*Kors v. Carey, 158 A.2d 136 (Del. Ch. 1960).

1. E.g., Hall v. Trans-Lux Daylight Picture Screen Co., 20 Del. Ch. 78, 171 Atl. 226 (Ch. 1934); Rosenfeld v. Fairchild Engine \& Airplane Corp., 309 N.Y. 168, 128 N.E.2d 291 (1955). See generally, Latcham \& Emerson, Proxy Contest Expenses and Shareholder Democracy, 4 W. RES. L. Rev. 5 (1952).

2. See Livingston, The American Stockholder 45 (1958).

3. See Emirerson \& Latcham, Shareholder Democracy 142 (1954); cf. Aranow \& Einhorn, Proxy Contests for Corporate Control 5 (1957).

4. See Livingston, op. cit. supra note 2, at 45.

5. From 1954 to June 30,1957, according to SEC records, there were 43 proxy contests for control. See Livingston, op. cit. supra note 2, at 47 n.7. For several examples of proxy contests won by insurgents, see KARR, FIGHT FOR CoNTROL (1956).

6. For a compilation of the state law relating to the power of a corporation to purchase its own shares, see appendix A.

7. The law in Great Britain is that no company may purchase its shares for any purpose. Trever v. Whitworth, 12 App. Cas. 409 (1887). One of the principal considerations of the House of Lords was the passible use of the power for the purpose of retaining control:

Can it be contended that when the policy of directors is assailed they may spend the capital of the company in keeping themselves in power, or in purchasing the retirement of inquisitive and troublesome critics?

... If shareholders think it worth while to spend money for the purpose of getting rid of a troublesome partner who is willing to sell, they may put their 
purchased its shares in order to give the directors majority control by reducing the total number of shares outstanding, the purchase was a breach of the directors' fiduciary duty and a willful disregard of the rights of other shareholders. ${ }^{8}$ The court reasoned that retention of control was not a proper corporate purpose for which funds of the corporation could be spent. ${ }^{9}$ The decision was based on an analogy to the law of that state which forbids the sale of treasury shares for the purpose of ensuring the incumbent directors' control of the corporation, ${ }^{10}$ holding that there is no significant difference between manipulating corporate control by causing the corporation to buy its shares or by causing it to sell shares. ${ }^{11}$ The same general conclusion is suggested by dictum in a Wisconsin case: although the directors' purpose in effecting the corporation's purchase was found not to be the creation of a controlling interest, the court indicated that, had the purpose been retention of control, the purchase would have been a violation of the directors' duty. ${ }^{12}$ Although reference to "the purpose" of a purchase may convey an oversimplified view of director motivation in such a transaction, judicial determination of such issues is itself necessarily oversimplified. The phrase may fairly be interpreted as a finding that the forbidden purpose was the principle reason for the transaction.

An exception to these decisions has been created in situations where the purchase of shares is justified by some other corporate purpose, such as the need to reduce outstanding shares, ${ }^{13}$ even though the purchase may in fact solidify management's control. This distinction becomes blurred when the directors cause the corporation to purchase its stock because they believe that their continued control will benefit the corporation. If desire to retain control bars the purchase, management will be unable to head off a bid for control by

hands in their own pockets and buy him out, though they cannot draw on a fund in which others as well as themselves are interested.

Id. at 435-36 (Lord Macnaghten).

8. Anderson v. Albert \& J. M. Anderson Mfg. Co., 325 Mass. 343, 90 N.E.2d 541 (1950).

9. Id. at $346-47,90$ N.E.2d at 544.

10. Elliott v. Baker, 194 Mass. 518,80 N.E. 450 (1907).

11. Anderson v. Albert \& J. M. Anderson Mfg. Co., 325 Mass. 343, 346-47, 90 N.E. 2d 541, 544 (1950) ; cf. Albert E. Touchet, Inc. v. Touchet, 264 Mass. 499, 507, 163 N.E. 184, 187 (1928) ; L. E. Fosgate Co. v. Boston Mkt. Terminal Co., 275 Mass. 99, 175 N.E. 86 (1931).

12. Gilchrist v. Highfield, 140 Wis. $476,478,123$ N.W. 102, 103 (1909). The purpose of the purchase was found to be the withdrawal from the corporation of one of the two principal shareholders, to resolve an inability to work together. Id. at $476,123 \mathrm{~N}$.W. at 102.

Cf. Dunn v. Acme Auto \& Garage Co., 168 Wis. 128, 169 N.W. 297 (1918) (sale of .treasury stock); Luther v. C. J. Luther Co., 118 Wis. 112, 94 N.W. 69 (1903) (sale of unissued shares).

13. Martin v. American Potash \& Chem. Co., 33 Del. Ch. 234, 92 A.2d 295 (Sup. Ct. 1952) ; see Gilchrist v. Highfield, 140 Wis. 476, 123 N.W. 102 (1909) (to break management deadlock) ; cf. Yasik v. Wachtel, 25 Del. Ch. 247, 255-56, 17 A.2d 309, 312-13 (Ch. 1941) (issuance of shares for services rendered). 
unsavory insurgents. On the other hand, if the directors are permitted to use corporate funds to make such stock purchases, their ability to secure their own position against shareholder attack will be significantly increased. An early Massachusetts' decision seems to have rejected the notion that manipulation of stock to retain control can be justified by the directors' belief that such manipulation will benefit the corporation. ${ }^{14}$ Delaware courts, however, have recently held that retention of control might be a proper corporate purpose if, absent fraud or unfairness, the reason for purchasing the shares was to eliminate a stockholder whose policy was at odds with that of the current management. ${ }^{15}$

The extent of this Delaware doctrine is illustrated by the recent case of Kors v. Carey. ${ }^{16} \mathrm{~A}$ minority shareholder brought a derivative action against the directors of Lehn \& Fink Products Corporation alleging that the use of corporate rather than personal funds to purchase a large block of the corporation's stock ${ }^{17}$ held by another corporation, United Whelan, was improper. The plaintiff maintained that the purpose of the purchase was self-serving retention of control by the directors, and that a purchase for that purpose was a breach of the directors' duty to the corporation. The directors based their defense principally on the grounds that, in view of the "quick profit" business record of United Whelan and its dominant shareholder, Charles Green, United Whelan's holding of a significant block of Lehn \& Fink stock posed a threat to the distinguished business reputation established through the incumbent management's traditional manufacturing and distribution policies. ${ }^{18}$

The Delaware Court of Chancery upheld the purchase. The court, relying on a previous Delaware decision, ${ }^{19}$ first concluded that purchase of shares for the purpose of eliminating a challenge to management's control was not per se invalid. ${ }^{20}$ The court then looked to the propriety of the purchase in the in-

14. Elliott v. Baker, 194 Mass. 518, 522-23, 80 N.E. 450,452 (1907). $1952)$.

16. 158 A.2d 136 (Del. Ch. 1960). The case involved three actions: first, an action by Bertha Kors against the directors of Lehn \& Fink Products Corp. and the corporation; second, an action by Bertha Kors against United Whelan Corporation; and third, a cross-claim by United Whelan against Lehn \& Fink. Id. at 137-38. This note deals only with the first action.

17. United Whelan had purchased 60,200 shares of Lehn \& Fink stock, amounting to approximately $16 \%$ of the 400,000 shares issued and outstanding. See $i d$. at 139 .

18. Id. at 139-40. Also, United Whelan was a customer of Lehn \& Fink and the directors of Lehn \& Fink feared alienation of its other customers if it were to become dominated by United Whelan. The management also feared prosecutions under the antitrust laws which might arise from abuse of this client-customer relationship.' Ibid.

19. Martin v. American Potash \& Chem. Co., 33 Del. Ch. 234, 92 A.2d 295 (Sup. Ct. 1952), discussed in text at note 15 supra.

20. The statutory authority for purchase by a Delaware corporation of its shares is Des. Code Ann. tit. 8, \& 160 (1953):

Every corporation . . . may purchase, hold, sell and transfer shares of its own capital stock; but no such corporation shall use its funds or property for the pur- 
stant case, and found that the plaintiff had not sustained the burden of proving "fraud, misconduct or abuse of discretion such as would compel a court of equity to find the individual defendants guilty of a breach of their fiduciary duty." 21 The court found as a matter of fact that the policies advocated by Green were inconsistent with those of the directors of Lehn \& Fink, and it concluded that the directors were correct in their expectation that such a divergence would have led to a contest for control. While the vice chancellor's opinion seems to agree with management's belief that the corporation would be damaged if control were lost to Green, ${ }^{22}$ an explicit finding to that effect was not made. ${ }^{23}$ Thus the decision seems to hold that the prospect of a change in corporate policy, believed by the directors to be detrimental, was itself sufficient justification for the purchase; proof that the insurgents would actually harm the corporation if they won control was not required. The court distinguished other Delaware cases holding manipulation of corporate stock to retain control illegal ${ }^{24}$ by remarking that those cases involved retention of control for selfish personal reasons, whereas in this case control was retained to defend management policy. ${ }^{25}$ This test is similar to that used in determining whether corporate funds can be used to pay the expenses of management in a proxy fight. ${ }^{20}$ Indeed, the court relied on the acknowledged right to spend corporate funds for proxy expenses as support for the corporate expenditure in Kors, and commented that the cost to the corporation was less than the cost of the proxy fight which was avoided. ${ }^{27}$

chase of its own shares of capital stock when such use would cause any impairment of the capital of the corporation.

21. 158 A.2d at 140 .

22. Id. at 139.

23. Compare McPhail v. L. S. Starrett Co., 257 F.2d 388, 395 (1st Cir. 1958) (applying Massachusetts law; court seems to make finding that insurgents have illegal motives) (dictum).

24. Macht v. Merchants Mortgage \& Credit Co., 22 Del. Ch. 74, 194 Atl. 19 (Ch. 1937) (extensive and complicated manipulations); see also Bowen v. Imperial Theatres, Inc., 13 Del. Ch. 120, 129, 115 Atl. 918, 922 (Ch. 1922) (no consideration for issue of new shares and shareholders' preemptive right violated); Kingston v. Home Life Ins. Co., 11 Del. Ch. 258, 263-64, 101 Atl. 898, 900 (Ch. 1917) (dictum); Yasik v. Wachtel, 25 Del. Ch. 247, 256, 17 A.2d 309, 313 (Ch. 1941) (dictum).

25. 158 A.2d at 141 .

26. See authorities cited note 1 supra.

27. 158 A.2d at 141 .

The court said in dictum that even if an improper motive had been shown, plaintiff had not suffered a legal injury. The court reasoned that plaintiff still had a right to vote, that she never had a legal right to vote for a "Green sponsored management," and that, in fact, she as well as all other shareholders had benefited financially from the purchase because of the subsequent rise in the market value of Lehn \& Fink shares held as treasury stock by the corporation. $I d$. at 142 .

The finding that the plaintiff was financially benefited is not supported. While it is possible that the purchase may benefit the shareholders if their fractional ownership is increased by paying less than the worth of the shares eliminated, the court's reliance on the fact that the market value of Lehn \& Fink shares, purchased from United Whelan at 
The court's distinction between personal and policy motives is almost impossible to apply. Courts which use the same distinction to justify corporate payment of management's proxy contest expenses have recognized this diffculty. ${ }^{28}$ Even when one side principally attacks the ability, character, experience, or business reputation of its opponents, policy alternatives will usual$1 \mathrm{y}$ be presented as a matter of form. ${ }^{29}$ In this context, there is little chance of proving that the directors have spent money solely because they want to keep their jobs. If, as in Kors, the plaintiff bears the burden of proving the management's personal motives, almost any corporate purchase of an insurgent's shares can be justified. ${ }^{30}$

Conceding, however, that the directors who bring about the purchase are clearly defending their policy of management, the manner in which the corporate funds are used must still be justified as a proper exercise of their power. The Kors court's reliance upon the power of directors to expend a

$\$ 28$, had risen to $\$ 45-\$ 48$ per share, 158 A.2d at 138 , does not necessarily reflect this benefit; the market price of the stock may not reflect its value in terms of reduced participation, and even market value may decline if the large block is placed on the market again. Treasury shares are not considered an asset of a corporation, see PAToN, Accountants' Handbook 1008-09 (3d ed. 1945) ; Baker \& Carey, Corporations 1428 (3d ed. 1959), and if the shares are resold, no profit or loss can be considered realized, PATON, Advanced ACCOUNTing 548 (1941).

Financial injury was possible. The cost of the purchase of 60,200 shares was $\$ 1,715,700$, 158 A.2d at 138, financed by an insurance company loan, Brief for Defendant, p. 84. This change in the financial position of Lehn \& Fink could have reduced its opportunities for expansion and hindered efforts to obtain further credit.

Moreover, financial injury in the specific case may not be a necessary element if the directors have impinged on the voting rights of the shareholders. Nonfinancial injury seems to have been sufficient in analogous cases. See Anderson v. Albert \& J. M. Anderson Mfg. Co., 325 Mass. 343, 345-47, 90 N.E.2d 541, 543-44 (1950) (disregard of the rights of shareholders); Luther v. C. J. Luther Co., 118 Wis. 112, 123-24, 94 N.W. 69, $72-73$ (1903) (injury to stockholders need not be financial). Thus only the first premise of the court's dictum regarding injury need be disproved to support the action.

28. See Steinberg v. Adams, 90 F. Supp. 604, 608 (S.D.N.Y. 1950) (applying Delaware law); Hall v. Trans-Lux Daylight Picture Screen Corp., 20 Del. Ch. 78, 84-85, 171 Atl. 226, 228 (Ch. 1934). Courts continue to use this distinction, however, when considering the problem. See Hand v. Missouri-Kansas Pipe Line Co., 54 F. Supp. 649, 651 (D. Del. 1944) (motion for preliminary injunction denied, leaving question of whether or not there was involved a substantial question of policy for further hearing); Rosenfeld v. Fairchild Engine \& Airplane Corp.; 309 N.Y. 168, 128 N.E.2d 291 (1955). Only one early case has been found in which use of the distinction resulted in disallowing expenditures. Lawyers' Advertising Co. v. Consolidated Ry. Lighting \& Refrigerating Co., 187 N.Y. 395, 80 N.E. 199 (1907).

29. See Friedman, Expenses of Corporate Prozy Contests, 51 Colum. L. Rev. 951, 952-53 (1951). See also 34 CHI.-KeNt L. Rev. 154, 155 (1956).

30. See Friedman, supra note 29, at 953 :

The result of this legal shadow boxing is that rarely are management expenditures [in proxy contests] disallowed because deemed to be personal. Thus, in actuality the management has a call upon the corporation treasury no matter what form the issue between it and the minority may take. 
reasonable amount of corporate funds to defend their policies in a proxy fight is inappropriate. The policy underlying the allowance of proxy expenditures is to inform the shareholder-electorate so that it may vote intelligently. ${ }^{31}$ This policy is not served by corporate expenditures which eliminate the occasion to vote and a fortiori the need to inform the shareholders of the competing policies. The only common characteristic of proxy expenditures and expenditures to purchase an insurgent's shares is that both help management to win the battle of control-an unlikely justification for either.

Moreover, the use of corporate funds to buy out insurgents is offensive to the underlying premise of the proxy-expenditure doctrine-that decisions about policy and management in contests for control should be made by the stockholders. Here the powers of the directors are used to interfere with the operation of the corporation's electoral process. Admittedly, all stockholders still have the power to vote and to pass upon management's policy at the following election. But effective opposition to management within a publicly held corporation requires a shareholder with a nucleus of votes who is capable of mobilizing the scattered and generally unconcerned voters holding the balance of electoral power. ${ }^{32}$ By using corporate funds to remove this nucleus, the directors have in fact prevented this challenge from coming to a vote before all the stockholders. The fact that the insurgent has voluntarily withdrawn from a possible proxy contest should not obscure the role of the directors in effectuating such a withdrawal. The insurgent will probably be motivated by the expectation of profit from managing the enterprise. If part of that profit can be realized quickly, or if a better opportunity presents itself elsewhere, he can

31. See Hall v. Trans-Lux Daylight Picture Screen Corp., 20 Del. Ch. 78, 81, 171 Atl. 226, 227 (Ch. 1934) :

[T] he incumbent directors may with perfect propriety make such expenditures from the corporate treasury as are reasonably necessary to inform the stockholders of the considerations which the directors deem sufficient to support the wisdom of the policy advocated by them and under attack; and in the same communications which the directors address to the stockholders in support of their policy they may solicit proxies in its favor.

See Peel v. London \& N.W. Ry., [1907] 1 Ch. 5, 19 (obtaining the best expression of the corporator's views); Hand v. Missouri-Kansas Pipe Line Co., 54 F. Supp. 649, 650 (D. Del. 1944) ("inform stockholders") ; Rosenfeld v. Fairchild Engine \& Airplane Corp., 309 N.Y. 168, 173, 128 N.E.2d 291, 293 (1955) ("persuading the stockholders of the correctness of their position"). Winning insurgents may look to the corporation for reimbursement under the same theory. Ibid.; Steinberg v. Adams, 90 F. Supp. 604 (S.D.N.Y. 1950) (applying Delaware law).

See also Friedman, supra note 29, at 953; Latcham \& Emerson, supra note 1, at 14; Comment, 49 MicH. L. Rev. 605, 608 (1951); Note, Proxy Solicitation Expenses, 31 N.Y.U.L. REv. 825, 829 (1956).

32. See Manning, Book Review, 67 YALE L.J. 1477, 1483, 1487 (1958) (criticizing the shareholders' dependence upon insurgents); ARANOw \& ErNHORN, op. cit. supra note 3, at 19; LIviNgston, op. cit. supra note 2, at 44-46. For comments on the prevalent attitudes of shareholders, see EMIERson \& LATChaM, op. cit. supra note 3, at 10; LivingsToN, op. cit. supra note 2, at 26, 36-38, 42-43; Manning, supra at 1487 ("stubbornly uninterested in exerting control"). 
be expected to sell his holding, provided that the sale can be made expeditious$1 y$ and without depressing the value of his shares. To satisfy this final condition, someone with sufficient capital must purchase the potential insurgent's shares in one large transaction. While it cannot be said that but for the use of corporate funds such a transaction could not have been effectuated or that the insurgent would not have sold out under less profitable circumstances, the power to use corporate funds for this purpose will greatly facilitate the exit of the opposing shareholder, and may in a given case be determinative of whether or not the insurgent will sell out. ${ }^{33}$

The objection to this use of the directors' official powers is not based upon an assumption that the stockholders' voting right includes the right to have an insurgent for whom to vote. Obviously, the directors, as any other stockholders, could eliminate the insurgent by using their own funds to buy him out. $^{34}$ Indeed, the incumbent directors could purchase a majority of the voting shares and permanently foreclose any effective shareholder challenge to their control. Alternatively, the incumbents could reach an accord with the insurgents, ${ }^{35}$ or the insurgents themselves could decide to forego the contest for control. By any of these means, the neutral shareholders would be denied the opportunity to vote against management as effectively as if the corporation itself had purchased the insurgents' holdings.

The objection arises only when the directors, by using corporate funds, use their office to tamper with the electoral process. This exercise of power seems inconsistent with the division of function between directors and the stockholder-electorate which is contemplated in the statutory provisions stating that directors shall be elected by the shareholders. ${ }^{36}$ While the directors' action in Kors does not offend this provision as openly as would, for example, the act of directors reappointing themselves without any vote, ${ }^{37}$ arguably it

33. In many cases the cost to private purchasers would be prohibitive. The cost in Kors was $\$ 1,715,700$. See note 27 supra. Had such a purchase been made prior to other recent contests for control, such as the successful fights of Young for the New York Central and Green for United Whelan, or to preclude Green's unsuccessful bid for Twentieth Century-Fox, the cost would, likewise, have been great. Young controlled 800,000 shares, see KARR, op. cit. supra note 5, at 21, which in 1954 sold from $185 \%$ to $34 \%$, Moody, Transportation Manual a89 (1956). Green owned 87,000 shares of United Whelan, see KARR, op: cit. supra note 5, at 97, which in 1951 had a total market value of from $\$ 282,750$ to $\$ 445,875$, see Moody, Industrial Manual 1195 (1953). The 44,700 shares of Twentieth Century-Fox owned by Green, see KARR, op. cit. supra note 5, at 130, had a market value in 1953 of from $13 \% / 2$ to $21 \%$ per share, Moody, IndustrunL MANUAL a100 (1956).

34. See note 7 supra.

35. See Aranow \& Einhorn, op. cit. supra note 3, at 7; Livingston, op. cit. supra note 2 , at 48 .

36. E.g., Del. Code Ann. tit. 8, $\S \S 141,212,222$ (1953) ; Mass. Ann. Laws, ch. 156, §§ 22, 32 (1959); N.J. Stat. Airn. $\$ 14: 7-1$ (1939); see 2 Fletcher, Cyclopedia Corporations $\$ \S 283,285$ (perm. ed. rev. vol. 1954) ; Ballantine, Corporations $\$ 158$ (rev. ed. 1946); Note, 31 N.Y.U.L. REv. 825, 826 (1956).

37. See Johnston v. Automatic Steel Prods., Inc., 30 Del. Ch. 324, 60 A.2d 455 (Ch. 1948), aff'd, 31 Del. Ch. 469, 64 A.2d 416 (Sup. Ct. 1949) (bylaw and director action 
results in the same kind of interference with the corporation's electoral system. Courts have condemned other indirect forms of director interference, such as manipulation of control through the issuance of new ${ }^{38}$ or treasury shares, ${ }^{39}$ the voting of treasury shares, ${ }^{40}$ and the forced redemption of certain holdings. ${ }^{41}$ In contrast, the use of corporate funds to pay for management's proxy expenses does not transgress this separation of function, for there the final decision on the issue involved is left to the shareholders. ${ }^{42}$

pursuant thereto in creating new directorships and filling them as vacancies held illegal -right of shareholders to vote cannot be delegated) ; Penn-Texas Corp. v. Niles-BementPond Co., 34 N.J. Super. 373, 380, 112 A.2d 302, 306 (1955) (directors' change in bylaw postponing meeting and thus extending term of office held illegal). The court in Pcin-Texas quoted an 1883 case to the same effect:

That provision of the charter which declares that annual meetings of the stockholders shall be held for the election of directors, grants to the stockholders a highIbid.

ly important and valuable right, which the directors can neither defeat nor impair.

38. See Luther v. C. J. Luther Co., 118 Wis. 112, 94 N.W. 69 (1903) ; Ballantine, op. cit. stpra note 36, § 209; Annot., 138 A.L.R. 526 (1942). But see McPhail v. L. S. Starrett Co., 257 F.2d 388 (1st Cir. 1958) (dictum).

39. See Elliott v. Baker, 194 Mass. 518, 80 N.E. 450 (1907) ; Dunn v. Acme Auto \& Garage Co., 168 Wis. 128, 169 N.W. 297 (1918).

40. See Ex parte Holmes, 5 Cow. 426 (N.Y. Sup. Ct. 1826). This conduct is now usually prohibited by statute. See, e.g., DEL. CodE ANN. tit. 8, $\S 160$ (1953); MAss. AnN. Laws ch. 156, § 31 (1959); N.J. Stat. ANN. § 14:10-8 (1939); Ballantine, op. cit. supra note 36, § 176. For a rationale of this rule, see ARANow \& ErNHoRN, op. cit. supra note 3 , at 354 ("As a matter of equity these [treasury] shares should be denied the voting right, since the right, if it existed, would always be exercised by the management to perpetuate itself.").

41. See Starring v. American Hair \& Felt Co., 21 Del. Ch. 380, 191 Atl. 887 (Ch.), aff'd per cutriam, 21 Del. Ch. 431, 2 A.2d 249 (Sup. Ct. 1937); Greene v. E. H. Rollins \& Sons, 22 Del. Ch. 394, 2 A.2d 249 (Ch. 1937). Read together these cases indicate, by way of dicta, that if there were statutory power to redeem common stock, such power could not be used for the purpose of getting "rid of certain stockholders of a given class solely because their presence in the stockholding group was undesirable to the rest." Id. at 400-01, 2 A.2d at 252; Starring v. American Hair \& Felt Co., supra at 384, 191 Atl. at 890 .

42. The desirability of preserving the integrity of the stockholder electoral system may, of course, be disputed.

For the last generation, the prevailing school of thought among corporate reformers, writers and legislators has been that the key to ensuring managerial responsibility lies in the shareholder's power to vote.

Manning, supra note 32, at 1486. See Aravow \& EINHORN, op. cit. supra note 3; EMrERson \& Latcham, Shareholder Democracy (1954); Gilbert, Divideñds and DemocRACY (1956).

On the other hand, Manning, supra note 32, at 1490, presents for examination, an "arbitrary model" of a corporate structure which "abandons the a priori legal conclusion that the shareholders 'own the corporation' and substitutes the more restricted conception that the only thing they 'own' is their shares of stock." See also BerLe \& MEANs, ModerN Corporation and Private Property 354-55 (1940).

But since elimination of shareholder franchise would require the substitution of other controls, Manning, stpra note 32, at 1491, its possible desirability cannot weigh in a court's decision under the existing statutory scheme of control. 
The possible reasons for giving this decision-making power to the directors are not convincing. The opinion in the Kors case seems to suggest that erasing the opportunity for insurgents to gain control may itself be a proper end. ${ }^{43}$ Fear that the insurgents' business policy will harm the corporation, or that the insurgents may intend to defraud other stockholders seem to be urged as the reason for circumventing the eventual shareholder decision. Dicta in a First Circuit decision, McPhail v. L. S. Starrett Co., ${ }^{44}$ suggests that a reasonable fear of fraud may even justify the directors' forcing the insurgent out of a challenging position by issuing new stock to reduce his percentage holding. The insurgents' opportunity to gain control can bear fruit, however, only if enough uncommitted shareholders vote for the insurgents to give them a majority, or if the insurgents themselves buy a majority interest. In either case, according to any conception of shareholder-franchise, the insurgents would be entitled to control. Avoiding this result can be considered a proper end only if it is assumed that the shareholders are likely to make an unwise choice when solicited, and that the choice could better be made by the directors. To give the decision to the directors, however, will be to allow them the choice of whether or not they should continue in office. It is doubtful that decisions by persons so interested will, in the long run, protect shareholder interests better than the decisions of the shareholders themselves. ${ }^{45}$ Even where the likelihood of fraud is present, a court should consider whether the alternative means of protecting the corporation are so inadequate that it must sanction a further preventative which gives directors a powerful and practically uncontrollable ${ }^{46}$ weapon against stockholder challenges. If the directors' prediction of fraud is reasonable and is supported by evidence from present or prior transactions, the directors' ability to use that information in a proxy contest makes it likely that the insurgent will not be accepted by the shareholders. And even if the insurgent wins the proxy contest, or purchases control, the protection afforded by a suspecting shareholders' close scrutiny and the availability of equitable relief ${ }^{47}$ if and when fraud is attempted should not be discounted.

43. $158 \mathrm{~A} .2 \mathrm{~d}$ at 141 . The court's apparent equation of the costs of the purchase with the costs of a proxy fight seem to assume that the result would, or should, be the same in either case.

44. 257 F.2d 388, 395 (1st Cir. 1958). The shareholders gave prior approval of the issuance. Id. at 391 ; see text at notes 53-55 infra.

45. See Gottlieb v. Heyden Chem. Corp., 33 Del. Ch. 82, 88, 90 A.2d 660, 663 (Sup. Ct. 1952) :

Human nature being what it is, the law, in its wisdom, does not presume that directors will be competent judges of the fair treatment of their company where fairness must be at their own personal expense.

46. See text accompanying notes 28-30 supra.

47. See Ballantine, op. cit. supra note $36, \S 66$. Injunctive relief may also be available in some cases to prevent the suspected fraud from occurring. See, e.g., Bowman Shoe Co. v. Bowman, 21 IIl. App. 2d 423, 158 N.E.2d 112 (1959) (directors temporarily enjoined from drawing allegedly excessive salaries or voting their absolute majority shares, pending further proceedings); Riddle v. Mary A. Riddle Co., 140 N.J. Eq. 315, 324, 54 A.2d 607, 612 (Ch. 1947) (dictum: an injunction may be issued but only "upon imposing and persuasive proof"). 
Another reason for allowing directors to short-circuit the proxy contest is suggested by the Kors court's observation that the cost of the purchase was less than the cost of the avoided proxy fight. Proxy contests are indeed costly, perhaps even wasteful..$^{48}$ But since cost is a universal factor in all proxy fights, that ground alone seems an insufficient reason for avoiding a shareholder vote. The unspoken assumption in this argument is the belief that, with or without the proxy contest, the result would have been the same-that is, that the insurgent would have lost. This assumption is inconsistent with the fear of the insurgent which apparently justified the Kors purchase. But even if the only justification advanced is the directors' belief that the insurgent will fail, the argument remains dubious. It would seem impossible in most cases to make an accurate estimate of probable success before the proxy campaign begins. And if the insurgents' chances are so slight that such an appraisal can be made, should not that judgment by the directors lead them to reduce their own proxy expenses?

In the absence of a valid reason to sustain this power, directors should not be permitted to cause the corporation to purchase its shares if their motive is to preclude the challenge of an insurgent. There may be instances, however, in which the directors can justify the corporation's purchase on some independent ground, even though the result of the transaction is also to eliminate a potential challenger. ${ }^{49}$ Thus the motive of the directors must be proved to sustain a cause of action. In determining motive, the assignment of the burden of proof on this issue is crucial. Since the facts which indicate the motivation of such a purchase are probably accessible only to the directors, to compel the plaintiff to prove the intent of the purchase would impose an almost insurmountable burden, and would, in effect, insulate the directors' action from challenge. Thus it might be more realistic to shift the burden to the directors, after the plaintiff-shareholder makes a reasonable showing that the purchase resulted in the elimination of a shareholder whom the directors viewed as a potential insurgent. ${ }^{50}$ Although the burden of proof rests somewhat easier upon defendants than it would on plaintiffs, it may still be dispositive in many cases. This disadvantage seems consonant, however, with the general doctrine that directors must prove the fairness of corporate transactions which work to their personal advantage. .1 $^{1}$

In determining the appropriate remedy, the court should realize that the main impact of the relief will be deterrent rather than remedial since no

48. Cf. Manning, supra note 32 , at 1488 .

49. For examples of financial motives not related to the undesirability of the opposing shareholders, see cases cited note 13 supra.

50. See 9 Wigmore, Evidence $\S 2486$ (3d ed. 1940) (burden placed on party who presumably has a peculiar means of knowledge); Morgan, Some Observations Concerning Presumptions, 44 HARv. L. Rev. 906, 911 (1939).

51. See, e.g., Pepper v. Litton, 308 U.S. 295, 306 (1939); Zweifach v. Scranton Lace Co., 156 F. Supp. 384, 396-97 (M.D. Pa. 1957); Gottlieb v. Heyden Chem. Corp., 33 Del. Ch. 82, 88, 90 A.2d 660, 663 (Sup. Ct. 1952). But see Baron v. Pressed Metals of America, 
remedy could restore the status quo. Further, the relief must not injure the financial position of the corporation or its shareholders. The decision of the court will be complicated by intervening market fluctuations of the purchased shares and by the possibility that persons will be rewarded or punished unjustly by unrelated market events. Rescission seems inappropriate, because the selling stockholder may be able to resist on lack of notice, and because he may receive a windfall if the shares increase in value. One possible remedy is the requirement that the directors purchase the shares from the corporation, at current market price or at the purchase price, whichever is higher. Interest costs could also be added. ${ }^{62}$ The effect of such a remedy would be to place the directors in approximately the same position they would have been in if they had defended their position of control properly-with their own funds. Both the interest charge and the possibility of being forced to purchase the shares after a decline in market price are not always deterrents. If the directors had intended to buy and hold the stock, they would have had to incur the same risk and cost. For most, however, the remedy does impose a hardship by removing the opportunity to resell the shares on the market soon after buying out the insurgent-thus raising the interest cost and preventing sale in a falling market.

To say that directors cannot use corporate funds to eliminate a challenge to management and its policies is not to say that a majority of the stockholders cannot vote to buy out the insurgents with corporate funds. Admittedly, the issue before the shareholders in this case would not be exactly the same issue that the proxy contest would have presented, since the insurgent, presumably favoring the purchase, will not criticize management policies or advocate his own. Therefore, a choice between adverse policies is not expressly

35 Del. Ch. 325, 338, 117 A.2d 357, 364 (Ch. 1955), aff'd, 123 A.2d 848 (Del. Sup. Ct. 1956) ; Uccello v. Gold'n Foods, Inc., 325 Mass. 319, 321, 90 N.E.2d 530, 531 (1950).

Nearly every writer who has considered the granting of power to purchase the corporation's own shares has criticized it on the ground that it is used, with few exceptions, for undesirable purposes. See Dodd, Purchase and Redemption by a Corporation of Its Own Shares: The Substantive Law, 89 U. PA. L. Rev. 697-98, 706 (1941) ; Glenn, Treasury Stock, 15 VA. L. Rev. 625, 638-42 (1929); Kessler, Share Repurchases Uitder Modern Corporation Lazes, 28 FordeAM L. REv. 637-38 (1960); Levy, Purchase by a Corporation of Its Owon Stock, 15 Mins. L. Rev. 1, 5-11 (1930); Nemmers, The Power of a Corporation To Purchase Its Owen Stock, 1942 WIs. L. REv. 161, 165-67; Nussbaum, Acquisition by a Corporation of Its Owen Stock, 35 Coluar. L. Rev. 971, 978-81 (1935); Note, 59 Y YLE L.J. 1177, 1179 (1950). But see Wormser, The Power of a Corporation To Acquire Its Own Stock, 24 Y ALE L.J. 177 (1915).

52. The legal interest, which is $6 \%$ per annum in Delaware, DeL. Code ANN. tit. 6, $\S 2301$ (1953), would be the proper rate to charge because that is the rate the corporation might be able to earn had it used its assets other than to purchase treasury shares. If, however, the financing of the purchase cost the corporation more than the legal rate, the directors should be made to reimburse the corporation to the extent of its additional expense. In Kors, the interest rate to finance the purchase was $51 / 8 \%$ per annum. Brief for Defendant, p. 84. 
before the shareholders. Rather, those voting to authorize the purchase are expressing their wish that this insurgent be encouraged not to seek the vote, or the shares, of their fellow shareholders. If the shareholders are fully informed, this would seem to be a proper course of shareholder action. The difficulty with this procedure is that the information given the shareholders is likely to be inadequate. No rebuttal to management's warning of danger to the corporation can be expected, since both management and the insurgent have a common interest in persuading the shareholders that the purchase is desirable. ${ }^{63}$ This probability should not lead to the conclusion that the shareholders cannot authorize the directors to buy out an insurgent. There will be cases, particularly when the corporation is small or when the insurgent is well known, in which the electorate is fully informed. Since the abuse arises from insufficient disclosure, perhaps the appropriate check is to set a high standard regarding the completeness of disclosure before approving the authorization. Similarly, a statute requiring that every non-pro-rata purchase by a corporation of its own shares receive prior authorization by more than a simple majority might counteract the potential lack of disclosure. Of those statutes which, under certain circumstances, require authorization before a corporation can purchase its stock, most require more than a simple majority. ${ }^{54}$ Although courts might also require, by reference to a doctrine sometimes employed in fraud cases, ${ }^{55}$ that only the

53. The danger of misinformation is not of the sort that will violate SEC disclosure requirements, see 17 C.F.R. $\$ 240.14 a-1$ to $240.14 a-10$ (Supp. 1960), because the crucial element is an unchallenged management opinion about the future action of someone else.

54. See Alaska Comp. Laws Ann. $\S 36-2 A-13$ (Supp. 1957) (certain financial limitations waived if $2 / 3$ of those entitled to vote concur) ; ConN. GEN. STAT. § 33-63 (1958) (absolute requirement of approval of $3 / 4$ of all capital stockholders voting at a special meeting unless purpose is to prevent loss upon a debt) (to be replaced Jan. 1, 1961 by Conn. Gen. Star. ANn. $\$ 33-358$ (Supp. 1959) (certain financial limitations waived if $2 / 3$ of the shareholders of each class concur)) ; LA. REv. STAT. ANN. § 12:23(5) (1951) (purchase for purpose other than specified permitted if $2 / 3$ of the shareholders of each class concur); N.H. REv. STAT. ANN. \& $294-28$ (1955) (certain financial limitations waived if $2 / 3$ of those entitled to vote concur); N.D. REV. CoDE $\$ 10-1905$ (Supp. 1957) (certain financial limitations waived if $2 / 3$ of those entitled to vote concur); OHro Rev. CoDE ANN. \& 1701.35 (Page Supp. 1959) (purchase for purpose other than specified permitted if $2 / 3$ of the shareholders of each class concur unless the articles provide otherwise); ORE. Rev. Stat. \& 57.035 (1959) (certain limitations waived if $2 / 3$ of those entitled to vote concur); TeXAs BUS. CORp. CoDE ANN. art. 2.03 (1956) (certain financial limitations waived if $2 / 3$ of the shareholders of each class concur); Wrs. Stat. ANn. $\$ 180.385$ (1957) (certain limitations waived if $2 / 3$ of the shareholders of the same class and each class of equal or prior rank concur). But see N.C. Gen. Stat. ANN. \& 55-52 (Repl. 1960) (unless purchase is pro rata except when for specified purposes, a majority of those entitled to rote must concur) ; PA. STAT. ANN. tit. 15, § 2852-701 (Supp. 1959) (certain limitations waived if a majority of those entitled to vote concur).

See also Kessler, supra note 51, at 687-88 (proposed statute).

55. Clamon v. Robertson, 164 Ohio St. 61, 72, 128 N.E.2d 429, 436 (1955); see S. Solomont \& Sons Trust v. New England Theatres Operating Corp., 326 Mass. 99, 114, 93 N.E.2d 241, 249 (1950) (question involved allowance of derivative suit. rather than ratification, which is distinguished, $i d$. at 111, 93 N.E.2d at 247). 
votes of distinterested shareholders be counted, this added safeguard seems inapposite. Since the issue is essentially a choice of management, counting the votes of interested directors would seem as proper here as in a proxy contest. And absent fraud, the vote of the interested shareholder might also be allowable. ${ }^{56}$

In theory, perhaps, subsequent shareholder ratification of the purchase would also sustain the directors' action. But the likelihood of perfunctory approval is even greater in this situation because the purchase has been completed and seems incapable of being undone. If allowing subsequent ratification to validate the purchase will in fact validate every such purchase, courts might close this loophole by holding that the purchase was for an "illegal purpose" and cannot subsequently be ratified by shareholders. While some jurisdictions disagree, ${ }^{\text {,T }}$ Delaware and New York courts have stated that ratification will not cure fraudulent, ultra vires or "illegal" acts. ${ }^{58}$ Since even Delaware, however, recognizes that less serious breaches, such as unauthorized acts, can be ratified, ${ }^{59}$ the court must first be able to characterize a Kors-type purchase as one of the more serious offenses. Dictum in Delaware cases characterizing the use of corporate funds for improper proxy expenditures as nonratifiable ${ }^{60}$ would seem to support this position.

56. See Note, 39 Calif. L. Rev. 268, 273 (1951). See generally Ballantine, op. cit. supra note $36, \S 71$.

57. See cases cited note $\mathbf{5 5}$ supra.

58. See, e.g., Mayer v. Adams, 141 A.2d 458 (Del. Sup. Ct. 1958); Toebelman v. Missouri-Kansas Pipe Line Co.. 130 F.2d 1016, 1022 (3rd Cir. 1942) ; Keenan v. Eshleman, 23 Del. Ch. 234, 245, 2 A.2d 904, 909 (Sup. Ct. 1938) ; Continental Securities Co. v. Belmont, 206 N.Y. 7, 18, 99 N.E. 138, 142 (1912).

59. Blish v. Thompson Automatic Arms Corp., 30 Del. Ch. 538, 64 A.2d 581 (Sup. Ct. 1948) ; see Kerbs v. California Eastern Airways, Inc., 33 Del. Ch. 69, 90 A.2d 652 (Sup. Ct. 1952) (stock option plan, a gift of corporate assets, could not be ratified; profit sharing plan merely voidable and could therefore be ratified).

60. See Campbell v. Loew's, Inc., 134 A.2d 565 (Del. Ch. 1957) ; Steinberg v. Adams, 90 F. Supp. 604, 609 (S.D.N.Y. 1950) (applying Delaware law).

Appendix A.

State Law Regulating a Corporation's Purchase of Its Shares

I. Purchase is prohibited in no jurisdictions.

II. Purchase is permitted in 7 jurisdictions in the absence of statutory or self-imposed restrictions, if made in good faith and without prejudice to creditors or other stockholders: Americanized Finance Corp. v. Yarbrough, 223 Ala. 266, 135 So. 448 (1931); Copper Belle Mining Co. v. Costello, 11 Ariz. 334, 95 Pac. 94 (1908); Bates Street Shirt Co. v. Waite, 130 Me. 352, 156 Atl. 293 (1931); Winchell v. Plywood Corp., 324 Mass. 171, 85 N.E.2d 313 (1949); Hoops v. Leddy, 119 N.J. Eq. 296, 182 Atl. 271 (Ch. 1936); Shayne of Miami, Inc. v. Greybow, Inc., 232 S.C. 161, 101 S.E.2d 486 (1957); VT. STAт. ANN. tit. 11, § 103 (1958).

III. Purchase is permitted in 11 jurisdictions if capital is not impaired: Colo. REv. Stat. AnN. § 31-1-25 (1953); Det. Code ANn. tit. 8, § 160 (1953); Ind. Stat. AnN. 
$\S 25-202$ (8) (Supp. 1960); Mich. Stat. Ann. § 21.10(h) (Supp. 1959); Neb. Rev. Stat. Ann. § 21-140 (1954); Nev. Rev. Stat. § 78.070(3) (1959); P.R. Laws ANn. tit. 14, § 1510 (Supp. 1957) ; R.I. Gen. Laws ANN. § 7-2-10(g) (1957) ; V. I. CoDE AnN. tit. 13, $\$ 106$ (1957); Wash. Rev. Code ANN. $\$ 23.01 .120$ (1958); W. VA. Code ANN. § 3051 (1955).

IV. Purchasing is permitted in 6 jurisdictions out of "surplus" only (with varying definitions of "surplus") : Ark. Stat. Ann. § 64-109(e) (Repl. 1957) ; FLA. Stat. AnN. $\S 608.13$ (9) (b) (1956); Minn. Stat. ANn. $\$ 301.22(6)$ (1947); N.Y. Penal Law $\S$ 664(5); S.D. CODE § 11.0303 (1939); TENN. CODE ANN. § 48-117(9) (1955).

V. Purchase is permitted in 19 jurisdictions with the limitation that it be out of "surplus," or without impairment of capital, but with those limitations waived if the purchase is for certain specified purposes, provided that the corporation will not become insolvent due to the purchase: Araska Comp. Laws AnN. § 36-2A-13 (Supp. 1957); CaL. CoRp. Code ANn. $\$$ 1705-1708; D.C. Code $\S 29-904 a$ (Supp. VIII 1960); GA. Code Ann. § 22-1828(d) (Supp. 1958); HawaII Rev. Laws § 172-25 (1955); Irr. Rev. Stat. ch. 32, § 157.6 (1957); Iowa Code AnN. § 496A.5 (Supp. 1959); Kan. Gen. Stat. Ann. $\$ 17-3004$ (Supp. 1959) ; Ky. Rev. Stat. Anv. § 271.135 (1953) ; Md. Ann. Code art. 23, § 32 (1957) ; Mo. ANn. Stat. $\$ 351.390$ (1952) ; Mont. Rev. Code ANN. § 15801 (9) (Repl. 1955) ; N.H. Rev. Star. ANN. § 294.28 (1955) ; N.D. Rev. Code § $10-$ 1905 (Supp. 1957) ; Orta. Stat. ANN. tit. 18, § 1.136 (1953); Ore. Rev. Stat. § 57.035 (1959) ; Pa. Stat. AnN. tit. 15, § 2852-701 (Supp. 1959); VA. Code ANN. § 13.1-4 (Repl. 1956) ; Wrs. Stat. ANn. \& 180.385 (1957).

VI. Purchase is permitted in 6 jurisdictions only as provided for in detailed statutes setting out limited specific uses of purchases: CoNN. GeN. STAT. \$ 33-63 (1958) (after Jan. 1, 1961, a new provision, placing Connecticut in category $\mathrm{V}$ will be in effect, see Conn. Gen. Stat. Ann. § 33-358 (1960)); La. Rev. Stat. Ann. \$ 12.23 (1951) ; N.C. Gen. Stat. Ann. § 55-52 (Repl. 1960); Оhio Rev. Code Ann. § 1701.35 (Page Supp. 1959) ; Texas Bus. Corp. Act Code Ann. art. 2.03 (1956); Utam Code Anv. § 16-2-16 (1953).

VII. There is no pertinent statutory or case law in 4 jurisdictions: Idaho, Mississippi, New Mexico, Wyoming. 